\title{
Assistive Technology for Elderly in Long-Stay Institutions \\ ORIGINAL
}

Ewerton José de Souza Maciel ${ }^{1}$, Eliane de Sousa Leite ${ }^{2}$, Maria do Carmo Andrade Duarte de Farias ${ }^{3}$, Rogéria Mônica Seixas Xavier de Abreu ${ }^{4}$, Edineide Nunes da Silva ${ }^{3}$, Francisco Fábio Marques da Silva ${ }^{5}$, Andréia Karla Anacleto de Sousa ${ }^{3}$, Cláudia Jeane Lopes Pimenta ${ }^{1}$, Alane Jusceni Menezes Cordeiro' ${ }^{1}$, Antônia Oliveira Silva ${ }^{6}$

\section{Abstract}

Introduction: With the various physiological and pathological changes relevant to the aging process, the elderly lose their autonomy and independence, limiting their ability for self-care and compromising the quality of life, which increases the need for social and professional support.

Objective: Verifying the knowledge about Assistive Technology by professionals and academics who work with the elderly in long term care services.

Method: This is a cross-sectional study with a quantitative approach, carried out in three long-stay institutions for the elderly from the city of Cajazeiras, Paraiba. The sample consisted of employees, volunteers, teachers and academics, totaling 50 participants. The results were tabulated and statistically analyzed using the software Statistical Package for Social Sciences, version 22.0, presented in tables and discussed according to the pertinent literature.

Results: The resources most identified by participants were the aid for daily life and practical life, architectural projects for accessibility and mobility aid. Some participants said they did not implement the Assistive Technology in their practice by not knowing the existing resources and its benefits, lack of training, limited resources and/or lack of Government resources and high cost of equipment.

Conclusion: Assistive Technology represents the next step in the search for active aging, being the devices of great value for the elderly, increasing their functional capacity, autonomy and quality of life.
1 Bachelor of Nursing, Federal University of Campina Grande. Cajazeiras, Paraiba, Brazil.

2 Doctoral Student of Nursing at the Federal University of Paraiba. João Pessoa, Paraiba, Brazil.

3 Academic Unit of Life Sciences, Teacher's Training Center, Federal University of Campina Grande. Cajazeiras, Paraiba, Brazil.

4 Graduate Program in Agri-food, Federal University of Campina Grande. Pombal, Paraiba, Brazil.

5 Academic Unit of Nursing, Teacher's Training Center, Federal University of Campina Grande. Cajazeiras, Paraiba, Brazil.

6 PhD in Psychology at the Institute of Labor Science and Enterprise - ISCTE, Lisbon, Portugal, Professor of Nursing at the Federal University of Paraiba. João Pessoa, Paraiba, Brazil.

\section{Contact information:}

\section{Eliane de Sousa Leite.}

झ elianeleitesousa@yahoo.com.br
Keywords
Elderly; Assistive Technology;
Long-Stay Institutions;
Self-Help Devices;
Homes for the Aged. 


\section{Introduction}

The arrival of aging is the physiological loss of functional abilities, which therefore predisposes to the appearance of chronic diseases, impacting the autonomy of elderly people and affecting their ability to develop the basic and instrumental activities of daily living [1].

In the face of various physiological and pathological changes relevant to the aging process, older people lose their autonomy and independence, with limited capacity for self-care, which in turn, affects the quality of life of the individual and increases the need for social and professional support [2].

In particular, where the elderly can no longer maintain self-care and the family did not have the necessary conditions to provide them with care, the choice should be institutionalized. This decision often aims to providing more qualified conditions, and also by the manifestation of that in situations of relative dependence, long-term care facility would provide a guarantee that care will take place effectively and possible changes are identified early and resolved [3].

Once institutionalized, the elderly need to learn to live together, need to adapt to environmental routine, which can be a stressor, which further enhances their level of addiction, causing them changes of psychological order [4].

Considering all the features presented by the institutionalized elderly, with presence or absence of disability, currently discussed in society, the use of resources that gives them functional skills and promote independent living and social inclusion is called Assistive Technology (AT).

This terminology was made official in Brazil by the Technical Assistance Committee (TAC) of the Special Secretariat of the Presidency of Human Rights of the Republic, and is considered as an interdisciplinary field of knowledge, encompassing products, resources, methodologies, strategies, practices and services to promote functionality, related to activities and participation of people with disabilities, disability or reduced mobility, to provide them with autonomy, independence, quality of life and social inclusion [5].

The use of AT by the Brazilian population is still limited, both for high-tech instruments, and for less sophisticated. This fact stems from the lack of knowledge of the population and possibilities of acquisition of such devices, particularly for lowincome social classes [6].

Regarding the professionals working with the elderly, studies in Brazil, primary health care, show a superficial knowledge of the AT and indications for the elderly are still limited [7].

With this understanding, we question: "What are the knowledge and the application about the AT by professionals and academics responsible for the care of institutionalized elderly?"

The study has relevance in the social and academic scope, about the use of AT for the institutionalized elderly; to have an integrating perspective in the face of health care; talk about the knowledge of the AT by professionals and the impact of the matter on the maintenance of autonomy, functionality and social inclusion of the elderly.

The objectives were to verifying the knowledge and application assigned to the AT by professionals and academics who work with the elderly in long term care institutions; describing the AT resources identified by professionals and academics in their daily practices and outlining the reasons that prevent the implementation of this technology.

\section{Method}

It is a cross-sectional study with a quantitative approach, conducted in three long-stay institutions for the elderly - LSIE, located in the city of Cajazeiras, Paraiba, Brazil, which are reference for the elderly who have no family or have been abandoned.

This study included professionals with employment relationships and volunteers $\mathrm{LSIE}$, teachers connected to the city's higher education institutions 
and graduate students in health courses who were in supervised internship or developed university extension activities with institutionalized elderly, namely: elderly caregivers, nurses, pharmacists, physiotherapists, a doctor, nursing technicians and students of nursing and physiotherapy.

The following inclusion criteria were adopted: for professionals and teachers - have minimal training about health of the elderly and develop activities with institutionalized elderly for at least six months; for academics - have completed at least $80 \%$ of supervised training or extension project. Did not take part of this investigation those who, while meeting the inclusion criteria, were absent from institutions in the period of data collection.

The variables were: age, sex, training time, institutional affiliation, training in gerontology area, geriatric knowledge and implementation of AT resources in their daily practice with institutionalized elderly.

For data collection it was used a self administered questionnaire and its execution took place between February and April 2015. To facilitate the application of the instrument there was made a visit to all the city's LSIE where the study was developed on alternate schedules (morning and afternoon), to connect and deliver the questionnaires to all employees and employees participating in the survey. The results of the questionnaires were statistically analyzed using the IBM software Statistical Package for Social Sciences (SPSS) version 22.0. A descriptive statistical analysis of the data collected was performed, where it is used the percentage, which were presented in tables.

The research project was approved by the Research Ethics Committee of the School Santa Maria, Protocol 31031714.3.0000.5180. With respect to the items shown in Resolution 466/12 of the National Health Council, which regulates research with humans [8]. The completion of the questionnaire took place only with the prior express consent of the participant, formalized by the signing of the Term of Consent.

\section{Results}

\section{Characterization of the research participants}

The study population consisted of 50 participants, 32 were female. Regarding the age group, 18 were between 18 and 25 years old, followed by the age group between 26 and 30 and over 40, with 10 participants each; 7 participants were between 36 and 40 years old and 5 between 31 and 35 .

Table 1 shows the relationship between vocational training and training time the target of the study population. It is observed that relating to vocational training, the nursing technicians accounted for more. Referring to the training time, between 3 and 5 years and between 11 and 15 years were the most cited, with seven participants each.

Table 1. Relationship between vocational training and training time. Cajazeiras, PB, 2015*.

\begin{tabular}{|l|c|c|c|c|c|c|c|}
\hline \multirow{2}{*}{ Professional Training } & \multicolumn{7}{c|}{ Training Time (in years) } \\
\cline { 2 - 7 } & $<1$ & 1 e 2 & 3 e 5 & 6 e 10 & 11 e 15 & 16 e 20 \\
\hline Elderly Caregiver & - & 2 & - & 2 & - & - \\
\hline Nursing Technician & - & 2 & 3 & 1 & 5 & - \\
\hline Nurse & - & 1 & 2 & 2 & - & - \\
\hline Doctor & 1 & - & - & - & - & - \\
\hline Physiotherapist & - & - & 2 & - & - & - \\
\hline Pharmacist & - & - & - & - & - & - \\
\hline
\end{tabular}


Table 2 presents the level of improvement of study participants.

Regarding the type of relationship maintained with long-term care facility, 16 participants have employment, seven were teachers, seven identified themselves as volunteers. Among academics, four were in supervised training and 16 participated in extension project.

Table 2. Level of improvement of study participants. Cajazeiras, PB, 2015.

\begin{tabular}{|l|c|c|}
\hline \multicolumn{1}{|c|}{ Level of improvement } & $\boldsymbol{f}$ & $\%$ \\
\hline Training & 4 & 8.0 \\
\hline Vocational course & 13 & 26.0 \\
\hline Graduation & 1 & 2.0 \\
\hline Specialization & 7 & 14.0 \\
\hline Mastership & 4 & 8.0 \\
\hline Doctorate & 1 & 2.0 \\
\hline Academic in supervised internship & 4 & 8.0 \\
\hline Academic in extension project & 16 & 32.0 \\
\hline & Source: & Research data. \\
\hline
\end{tabular}

\section{Data related to Assistive Technology}

When asked about the time they became aware of the AT, 14 participants reported on their work environment; 12, during graduation; 2, in graduate school; 3, during professional course; 2, capacity building; 7 , at other times and 10 participants were unaware of the AT.

When asked about the application of AT in their practices with the elderly, 34 implemented it. It is noteworthy that the number of participants who did not implemented AT overlapped those who said unaware it previously.

Table 3 presents the categories of features and products identified as available and/or applied by participants who reported the use of AT in their daily practice, emphasizing: aid for daily life and practical life (21.7\%), aid mobility (20\%) and architectural projects for accessibility (17.4\%). Such categories followed up the classification cited by Bersch [13] for AT resources.
Table 3. Categories of resources and products in AT. Cajazeiras, PB, 2015.

\begin{tabular}{|l|c|c|}
\multicolumn{1}{|c|}{$\begin{array}{c}\text { Categories of resources and } \\
\text { products in AT }\end{array}$} & $f$ & $\%$ \\
\hline $\begin{array}{l}\text { Aid for daily life and practical life } \\
\text { Augmentative and alternative communication }\end{array}$ & 25 & 21.7 \\
\hline Accessibility to a computer & 1 & 2.6 \\
\hline Architectural projects for accessibility & 20 & 17.4 \\
\hline Orthotics or prosthetics & 14 & 12.2 \\
\hline Posture & 5 & 4.3 \\
\hline Mobility aid & 23 & 20.0 \\
\hline Aid for visually impaired total or partial & 5 & 4.3 \\
\hline Assistance for hearing impaired total or partial & 1 & 0.9 \\
\hline Mobility in vehicles & 2 & 1.7 \\
\hline Sport and leisure & 16 & 13.9 \\
\hline
\end{tabular}

In Table $\mathbf{4}$ are willing results of the reasons that prevent the implementation of the AT by the participants. Among them, included: unaware the existing AT resources (15.7\%), did not feel able to implement it (15.7\%) and unaware of their benefits (13.7\%).

Table 4. Reasons for the non implementation of AT. Cajazeiras, PB, 2015.

\begin{tabular}{|c|c|c|}
\hline $\begin{array}{l}\text { Reasons for the non } \\
\text { implementation of AT }\end{array}$ & $f$ & $\%$ \\
\hline The clientele doesn't need AT & 1 & 2.0 \\
\hline I do not know the capabilities of existing AT & 8 & 15.7 \\
\hline Difficulty of finding TA equipment in the market & 4 & 7.8 \\
\hline I do not know of the benefits of AT & 7 & 13.7 \\
\hline I don't feel qualified to implement the use of AT & 8 & 15.7 \\
\hline The AT list for public services are reduced & 5 & 9.8 \\
\hline $\begin{array}{l}\text { The service I work for does not offer this type } \\
\text { of resource }\end{array}$ & 1 & 2.0 \\
\hline $\begin{array}{l}\text { Limited resources and/or insufficient } \\
\text { government resources }\end{array}$ & 6 & 11.8 \\
\hline $\begin{array}{l}\text { Limited resources and/or insufficient resources } \\
\text { of my clients }\end{array}$ & 4 & 7.8 \\
\hline Delay or difficulty for grant of AT products & 2 & 3.9 \\
\hline High cost of equipment of AT & 5 & 9.8 \\
\hline
\end{tabular}

Source: Research data. 


\section{Discussions}

The current situation on the demographic transition in Brazil and challenges in the achievement of aging with quality of life drive to seek solutions that promote greater functionality of the elderly population, since approximately $23.9 \%$ of the population have some form of disability, among which $67.7 \%$ are elderly [9].

When the elderly with compromised functionality is usually the family seeks help in instruments, equipment and services that are offered by the AT, so one can perform his basic and instrumental activities of daily living. Therefore, the use of AT is a necessary strategy for the active inclusion of older people in society, at home, long term care facilities or hospitals [10].

The refered research sought knowledge and application attributed to AT in the daily practices of professionals and academics working in LSIE. Given the results of this can be observed a predominance of females in participating, and a relatively young population. It is believed that this takes place due to the significant number of academic study participants. The insertion of the gym in the health services has to be very positive as it provides the exchange of experiences among professionals and students, as well as providing major contributions in shaping the future career of these.

Corroborating this study, Silva, Fonseca and Santos [11] stated that the presence of students in an institution brings a constant updating for health professionals, since these are renovation factors, although some professionals do not have this critical view. Academic possible to service a greater link between educational institutions and health services, promoting the development of various activities, particularly those related to research and practices with current knowledge learned in higher education institutions.

Regarding vocational training, there is a predominance of nursing professionals. This fact has its explanation in the profile of the caregiver present in these professionals, considering that the Federal Nursing Council [12] reported that nursing represents about $50 \%$ of the 3.5 million health professionals working in Brazil.

Regarding the improvement, among higher education professionals target of the study, there is a trend in the search for further refinement of knowledge, as the postgraduate appears predominant form between them. The search for improvement of knowledge through graduate school strengthens the competitiveness of the labor market, as well as demonstrates a search for improvement of knowledge and experience obtained, and provides better care to elderly residents in LSIE.

Referring to the AT, it was evident that the majority (80\%) of participants has some knowledge and the work environment as indicated by the sample as a place where we got this knowledge. Scholars in AT area [13] report a concern in this regard, because when knowledge is learned in the workplace, it may not be the most appropriate, because there is no guarantee on the quality of the information transmitted.

In September 1990, Congress decreed [14] the law 8080/90, considered a first milestone that consolidated the debates of the 8th National Health Conference, the creation of the Unified Health System in Brazil. The law determines its fundamental principles and objectives, in addition to the duties of each of the governmental spheres. In it, the continuing education of health professionals is the duty of the State, through the formation of standing committees of integration between health services and higher and vocational education institutions.

There are available various works, printed and electronic media, referring to AT, highlighting, for professionals who work with the elderly, the "Caregiver's Guide Elder" [15], prepared by the Special Secretariat for Human Rights, which presents a chapter entitled "what every caregiver of elderly people should know about Assistive Technology". In 
addition, there are online courses available through the partnership between the University of Brasilia and the Ministry of Health, the creation of the website of "Open University of SUS, UNA-SUS" [16], for the improvement and continuing education for health professionals working in the National Health System, in a virtual environment with free materials and free access, highlighting the "therapeutic use of assistive technology", created as part of the National Plan of rights of Persons with Disabilities - Live without limit [17].

It was cited also by the participants of this study, that part of the knowledge of the AT was obtained during graduation. This statement presents fairly ambiguous, given that the introduction AT's teaching, graduation in Brazilian educational institutions, is a very recent practice, seen in occupational therapy courses, but with expectations of this writing the curriculum of other healthcare courses in the future [18].

In this sense, the Technical Assistance Committee, a body responsible for the training of qualified human resources and the development of studies and research on the topic in Brazil in a survey conducted to trace the use of AT in higher education institutions, found that most of these do not have qualified human resources, researchers in the field and not in the discipline in the curricular matrices of most of their courses [19].

When asked about the implementation of the AT in the daily routine, the resources most frequently cited by participants were the aid for daily life and practical life, architectural projects for accessibility and mobility aid. These results are similar to those found by Andrade and Pereira [7], which found, in most cases, that the use of AT by the elderly is related to the development of functional activities of daily living, intended to increase the independence, autonomy and level of safety, and reduce costs with possible fall-related hospitalizations.

About AT equipment design and the benefits achieved in the development of activities of daily living of institutionalized elderly, it was found that with the use of simple materials and easy to purchase, it was possible to extend the elderly independence level for the activities of daily life, food, clothing and hygiene [20].

A study [7] reinforces that AT has the potential to eliminate gaps between the performances of the individual and the demands that the activities of daily living require. According to researchers, both the old as his caregiver can get benefits from this practice, for greater independence of the elderly makes it safer practice caregiver, resulting in a lower load stress and decreased energy expenditure.

Regarding the lack of AT by the professionals surveyed, what is observed in Brazil is the absence of a public policy to encourage the teaching, development and production of AT. This contributes greatly to the professionals and society in general aware of the potential of this technology to the autonomy of elderly and disabled people, and its real contribution to improving the quality of life and social integration of these people [21].

Success in the practical application of AT is linked to user participation, taking into account their socio-cultural context. Bersch [13] explains that the AT service should seek to permit the user so that it remains informed and the application of this takes place in a competent way.

To justify ignorance and non-use of AT, another factor cited by survey participants was the lack of resources from the government. Researchers clarify [6] that the National Health System works with a fixed AT resources table, to be granted to people with disability. Thus one cannot meet the demands not provided.

The free provision of orthotics, prosthetics and aids to handling is guaranteed by decree number 185 of June $5^{\text {th }}, 2001$, health care office. Through this, the Health System makes available "when necessary, prescription, evaluation, adaptation, training and monitoring of bracing dispensation, prosthesis and/or mobility aids and family counseling" [22]. 
It is important to emphasize the fact that one of the participants believes that the AT is not necessary for the elderly by them met. Such a statement goes against the data published by the Brazilian Institute of Geography and Statistics [23], indicating that the prevalence of physical disability in the elderly in the State of Paraiba is up to $35 \%$. Therefore, it is believed that the institutionalized elderly or not, can benefit from the time this feature is prescribed and used correctly, with a view to its main function: to overcome disabilities, promoting functionality and social inclusion.

\section{Conclusion}

The AT is the next step in the search for healthy aging. However, there is a need for further deepening in the thematic front of the shortage of articles published and indexed in national databases. Therefore, it is necessary to raise awareness among health professionals and researchers about the benefits that the use of this technology makes it possible for older people with their social inclusion, the conquest and the practice of citizenship.

\section{References}

1. Azevedo LM, Oliveira KMV, Alchieri JC, Nunes VMA. Losses of functional capacity in elderly institutionalized in the city of Natal/Rio Grande do Norte. J. res.: fundam. care. online 2014. abr./jun. 6(2): 485-92. DOI: dx.doi.org/10.9789/21755361.2014v6n2p485

2. Papaléo Netto M. Tratado de Gerontologia. $4^{a}$ edição. São Paulo. Atheneu; 2010.

3. Santos NO, Beuter M, Marilene N, Girardon-Perlini O, Paskulin LMG, Leite MT et al. Percepção de trabalhadores de uma instituição de longa permanência para idosos acerca da família. Texto Contexto - Enferm., Dec 2014; 23(4): 971-78. DOI: dx.doi. org/10.1590/0104-07072014003170013.

4. Neves HMF. Causas e Consequências da Institucionalização de Idosos. Dissertação (mestrado em gerontologia). Departamento de Ciências Médicas, Programa de Pósgraduação em Gerontologia, Universidade da Beira Interior. Covilhã, Portugal. 2012; 87p. Available from: http://ubithesis. ubi.pt/bitstream/10400.6/1209/1/CAUSAS CONSEQUENCIAS INSTITUCIONALIZA\%C3\%87AO_IDOSOS.pdf

5. Brasil. Secretaria Especial dos Direitos Humanos da Presidência da República. Coordenadoria Nacional para Integração da Pessoa Portadora de Deficiência - CORDE. Comitê de Ajudas Técnicas, Ata da VII Reunião. Brasília, 2007. Available from: http://www. mi.gov.br/sedh/ct/corde/dpdh/corde/comite at.asp.

6. Bersch RCR, Moraes HS, Passerino LM, Batista V, Amaral FG. Fatores Humanos em TA: Uma Análise de fatores Críticos nos Sistemas de Prestação de Serviços. Plurais: revista multidisciplinar da UNEB. 2010; 1(2): 132-52. Available from: http://www. revistas.uneb.br/index.php/plurais/article/view/873.

7. Andrade VS, Pereira LSM. Influência da tecnologia assistiva no desempenho funcional e na qualidade de vida de idosos comunitários frágeis: uma revisão bibliográfica. Rev. Bras. Geriatr. Gerontol., 2009; 12(1): 113-22. ID: lil-514975. Available from: http://www.crde-unati.uerj.br/img_tse/v12n1/ pdf/art_9.pdf.

8. Brasil. Resolução $n^{\circ}$ 466, de 12 de dezembro de 2012. Aprova normas regulamentadoras de pesquisas envolvendo seres humanos. Conselho Nacional de Saúde. Brasília: 2012. Available from: http://conselho.saude.gov.br/resolucoes/2012/ Reso466.pdf

9. Instituto Brasileiro de Geografia e Estatística. Censo Demográfico 2010. Rio de Janeiro, IBGE, 2014. Available from: http:// censo2010.ibge.gov.br.

10. Pelosi MB. O papel do Terapeuta Ocupacional na Tecnologia Assistiva. Cadernos de Terapia Ocupacional da UFSCar. 2005; 13(1):39-46. Available from: http://www. cadernosdeterapiaocupacional.ufscar.br/index.php/cadernos/ article/view/176. 
11. Silva TP, Fonseca APLA, Santos SMS. O Processo de avaliação do estágio extracurricular em saúde nas unidades de saúde do Rio de Janeiro. Enferm. Glob., 2011; 10(1): 1-10. Available from: http://revistas.um.es/eglobal/article/view/115331/109261.

12. Conselho Federal de Enfermagem. Pesquisa inédita traça perfil da enfermagem. [internet]. Brasília, 06 mai. 2015. Available from: $\quad$ http://www.cofen.gov.br/pesquisa-inedita-traca-perfilda-enfermagem 31258.html.

13. Bersch RCR. Introdução à Tecnologia Assistiva. [internet] Porto Alegre: Assistiva Tecnologia e educação, 2013. Available from: http://www.assistiva.com.br/Introducao Tecnologia Assistiva. pdf.

14. Brasil. Congresso Nacional. Lei $n^{\circ} 8080$, de 19 de setembro de 1990. Dispõe sobre as condições para a promoção, proteção e recuperação da saúde, a organização e o funcionamento dos serviços correspondentes e dá outras providências. Presidência da República. Brasília, 19 de Setembro de 1990. Available from: https://www.planalto.gov.br/ccivil 03/LEIS/L8080.htm.

15. Born T. Manual do cuidador da pessoa idosa. Brasília. Secretaria Especial dos Direitos Humanos, Subsecretaria de Promoção e Defesa dos Direitos Humanos; 2008. Available from: http:// www.sdh.gov.br/assuntos/pessoa-idosa/legislacao/pdf/manualdo-cuidadora-da-pessoa-idosa

16. Universidade Aberta do SUS-UNASUS. [Internet] Available from: http://www.unasus.unb.br/site/.

17. Plano Nacional dos Direitos da Pessoa com Deficiência. Secretaria de Direitos Humanos da Presidência da República, Secretaria Nacional de Promoção dos Direitos da Pessoa com Deficiência. 2013. Available from: http://www.pessoacomdeficiencia.gov. br/app/sites/default/files/arquivos/\%5Bfield_generico_imagensfilefield-description\%5D_0.pdf.

18. Pelosi MB, Nunes LROP. Formação em serviço de profissionais da saúde na área de tecnologia assistiva: O papel do terapeuta ocupacional. Rev. Bras. Crescimento Ddesenvolv. Hum. 2009; 19(3): 435-44. ID: lil-536905. Available from: http://www. revistas.usp.br/jhgd/article/viewFile/19931/22009.

19. Brasil. Subsecretaria Nacional de Promoção dos Direitos da Pessoa com Deficiência. Comitê de Ajudas Técnicas. Tecnologia Assistiva. Brasilia: CORDE; 2009. Available from: http:// www.pessoacomdeficiencia.gov.br/app/sites/default/files/ publicacoes/livro-tecnologia-assistiva.pdf.

20. Silva LC. O design de equipamentos de tecnologia assistiva como auxílio no desempenho de atividades de vida diária de idosos e pessoas com deficiência, socialmente institucionalizados. Dissertação (mestrado em design), Escola de Engenharia, Programa de pós-graduação em design, Universidade Federal do Rio Grande do Sul, Porto Alegre, RS. 2011. Available from: http://hdl.handle.net/10183/32601.
21. Albuquerque KF, Moreira MAP, Costa SMG, Costa CC, Patrício ACFA. Tecnologia Assistiva para pessoa idosa: revisão integrativa da literatura. Revista de Pesquisa: Cuidado é Fundamental. 2011; 3(5): 184-88. ID: bde-23316. Available from: http://www.seer. unirio.br/index.php/cuidadofundamental/article/view/1976/ pdf 540

22. Brasil. Secretaria de assistência à saúde. Portaria $n^{\circ} 185$, de 05 de junho de 2001. Altera a descrição dos serviços de códigos 18 e 05 constantes da Tabela de Serviço do Sistema de Informações Ambulatoriais do Sistema Único de Saúde - SIA/SUS e dá outras providências. Brasília, 2001. Available from: http:// dtr2004.saude.gov.br/susdeaz/legislacao/arquivo/Portaria 185 de $0506 \quad 2001 . p d f$

23. Instituto Brasileiro de Geografia e Estatística. Indicadores Sócio demográficos e de saúde no Brasil. [internet] Rio de Janeiro, IBGE, 2009. Available from: http://www.ibge.gov.br/english/ estatistica/populacao/indic sociosaude/2009/indicsaude.pdf

\section{Comment on this article:}
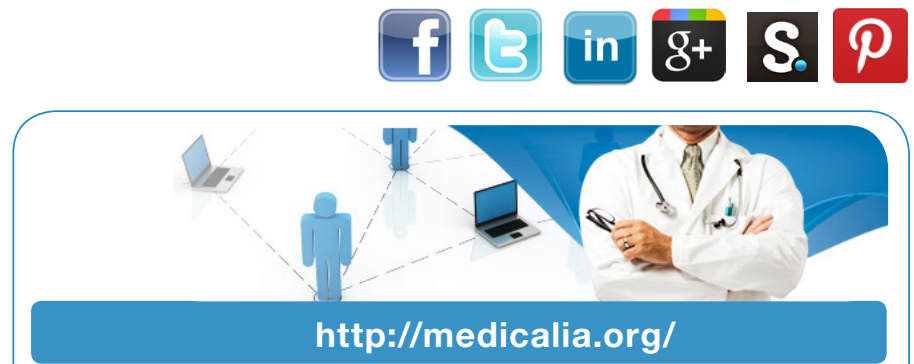

Where Doctors exchange clinical experiences, review their cases and share clinical knowledge. You can also access lots of medical publications for free. Join Now!

\section{Publish with iMedPub}

\section{http://www.imed.pub}

International Archives of Medicine is an open access journal publishing articles encompassing all aspects of medical science and clinical practice. IAM is considered a megajournal with independent sections on all areas of medicine. IAM is a really international journal with authors and board members from all around the world. The journal is widely indexed and classified Q1 in category Medicine. 